\title{
GLUCOSE TOLERANCE AND THE BLOOD-SUGAR CURVE IN CHILDHOOD.
}

\author{
BY
}

\author{
MARY L. GILCHRIST, M.B., Ch.B.
}

(From the Dept. of Pædiatrics, Glasgow University, and the Biochemical Laboratory, Royal Hospital for Sick Children, Glasgow.)*

\section{Glucose Tolerance.}

Within recent years glucose tolerance has been used as a means of investigating disturbances of carbohydrate metabolism, especially when following disorders of the endocrine system. In such tests it has generally been accepted that a normal adult, of about $60 \mathrm{kgrm}$. weight, can ingest and metabolize $100 \mathrm{grm}$. of glucose without the appearance of glycosuria. The ability to deal with more than this amount is considered evidence of an increased carbohydrate tolerance, and the presence of glycosuria following the ingestion of less than $100 \mathrm{grm}$. points to a decreased tolerance. In the case of children it has been customary to consider that there is an increased carbohydrate tolerance if more than $2 \mathrm{grm}$. of glucose per kgrm. of body weight can be ingested without the appearance of glycosuria.

This view of carbohydrate tolerance has not, however, met with universal acceptance. Samson Wright" says "It is difficult to understand the term ' increased sugar tolerance,' which is so frequently used, since nausea develops before the limits of ingestion are reached." He also states that a proportion of subjects develop very slight glycosuria with $300-500 \mathrm{grm}$. of glucose. Taylor and Hulton ${ }^{2}$ consider that in the majority of healthy adults there is no limit to the assimilation of glucose, but a survey of their findings shows that in 6 of their 25 cases glycosuria appeared with $200 \mathrm{grm}^{\text {. Gray }}{ }^{3}$ in his paper on 'Blood Sugar Standards' points out that of 129 apparently normal persons $40 \%$ showed glycosuria with $100 \mathrm{grm}$. of glucose, and Goto and $\mathrm{Kuno}^{4}$ also noted glycosuria after the ingestion of a similar amount in $62 \%$ of their cases. Benedict and Osterberg 5 , who hold that there is no absolute tolerance for sugar in the normal individual, report glycosuria in two cases after 40 and 60 grm. of glucose respectively.

In the present paper are recorded the results of the glucose tolerance test in 39 children varying in age between $1 \frac{1}{2}$ years and 12 years. In 28 (Group I) of these 39 children there was no reason for suspecting any disturbance of carbohydrate metabolism, but the remaining 11 children (Group II) were suffering from diseases in which it is generally supposed that such a disturbance exists.

The majority of the 28 children comprising Group I were suffering from chorea, but there were also 3 patients convalescent from rheumatic arthritis, 2 suffering from tæniasis, and one case each of rheumatic pericarditis, convalescent pneumonia, chronic pneumonia, congenital syphilis, chloroma and

* This work was done during the tenure of a Muirhead Scholarship. 
rickets. The children with chorea and those suffering from rheumatic infections were receiving daily 90 grains of sodium salicylate and 180 grains of sodium bicarbonate. These drugs, however, were omitted during the day of the test. Group II was further subdivided according as to whether or not it was possible to break the tolerance (Tables I and II). The test was discontinued when the child was actively sick with an amount of glucose larger by $1 \mathrm{grm}$. per $\mathrm{kgrm}$. of body weight than that tabulated. Seven of the children could not be induced to take more glucose than that recorded because of the fear that they would be sick.

The glucose, in amounts varying from 1 to 11 grm. per kgrms. of body weight, was given in place of breakfast after an all-night fast. The urine was collected afterwards for 4 hours at hourly intervals and tested for sugar with Fehling's solution. When there existed any doubt about the result the phenyl-hydirazine test was also carried out.

\section{Group I. Glucose tolerance test in 28 ' normal' children.}

Table I gives the details of the four cases in whom glycosuria was produced, and of these A.H. is the only one whose sugar tolerance can be said to be markedly reduced. This patient was examined daily for glycosuria for a period of two months, but the tests were always negative, and he never showed any symptoms of diabetes. The blood sugar curve after $22 \mathrm{grm}$. of glucose reached a value of $0 \cdot 208 \%$ in one hour, but fell below the fasting level in 2 hours. The tolerance in the other three cases was broken with quantities of glucose equal to 4,5 , and $6 \mathrm{grm}$. of glucose per $\mathrm{kgrm}$. of body weight respectively.

TABLE I.

Cases in which Glycosuria occurred.

\begin{tabular}{l|c|c|c|c|c|c|c}
\hline \multicolumn{1}{c|}{ Case } & Sex & $\begin{array}{c}\text { Age. } \\
\text { Years }\end{array}$ & $\begin{array}{c}\text { Weight } \\
\text { Kgrm. }\end{array}$ & $\begin{array}{c}\text { Glucose per } \\
\text { kgrm. of } \\
\text { body weight }\end{array}$ & $\begin{array}{c}\text { Amt. of } \\
\text { glucose. } \\
\text { Grm. }\end{array}$ & Disease & $\begin{array}{c}\text { Sugar } \\
\text { in } \\
\text { urine }\end{array}$ \\
\hline A.H. & M. & $10 \frac{1}{2}$ & $21 \cdot 8$ & $1 \cdot 0$ & 22 & Chorea & Trace \\
D.T. & M. & 10 & $25 \cdot 1$ & 4 & 105 & Chorea & $\begin{array}{c}\text { Rheumatism } \\
+ \\
\text { J.C. }\end{array}$ \\
F.McC. & F. & 5 & $17 \cdot 5$ & 5 & 121 & Chorea & Trace \\
\hline
\end{tabular}

All but one of the cases in Table II were able to take more than 2 grm. of glucose per kgrm. of body weight without either nausea or the appearance of sugar in the urine, and 16 of the $28(57 \%)$ were able to ingest a total of 100 grm. or more without glycosuria. The amount of glucose which children can take without nausea varies enormously, and seems to have little or no relationship to age or weight. The quantity varied from 30 to $270 \mathrm{grm}$. One child of $3 \frac{8}{1.2}$ years took a total of $110 \mathrm{grm}$. of glucose (i.e., $11 \mathrm{grm}$. per kgrm.) and another child of $10 \frac{1}{2}$ years was able to take only 67 grm. (i.e., 2.5 grm. per korm.) without nausea and sickness being produced. This fact (that of 
nausea) complicates any conclusions which may be drawn regarding sugar tolerance. 19 of these 28 children were able to take $4 \mathrm{grm}$. of glucose per kgrm. of body weight without glycosuria, and only in 2 of the 28 cases was the sugar tolerance broken with this or a lesser amount ( 1 grm. per kgrm. of body weight). It may therefore be generally concluded that the majority of normal children are able to ingest an amount of glucose equal to $4 \mathrm{grm}$. per kgrm. of body weight without glycosuria resulting.

TABLE II.

(Cases in which no Glycosuria Resulteid.

\begin{tabular}{|c|c|c|c|c|c|c|}
\hline Case & Sex & $\begin{array}{l}\text { Age. } \\
\text { Years }\end{array}$ & $\begin{array}{l}\text { Weight } \\
\text { Kgrm. }\end{array}$ & $\begin{array}{l}\text { Glucose per } \\
\text { kgrm. body } \\
\text { weight }\end{array}$ & $\begin{array}{l}\text { Amt. of } \\
\text { glucose. } \\
\text { Grm. }\end{array}$ & Disease \\
\hline J.W. & $\mathrm{M}$. & $4 \frac{1}{2}$ & $14 \cdot 8$ & 2 & 30 & Chr. pneumonia \\
\hline J.McL. & M. & $10 \frac{1}{2}$ & $26 \cdot 8$ & $2 \cdot 5$ & 67 & Rheumatism \\
\hline E. ('. & F. & $5 \frac{1}{2}$ & $16 \cdot 4$ & 3 & 49 & Pericarditis \\
\hline F.W. & F. & $2 !$ & $11 \cdot 8$ & 3 & 36 & Conv. pneumonia \\
\hline J.F. & M. & 12 & $27 \cdot 12$ & $3 \cdot 5$ & 100 & Severe chorea. \\
\hline N.G. & F. & 10 & $26 \cdot 36$ & $3 \cdot 5$ & 100 & , , \\
\hline M.H. & F. & 11 & 28 & $3 \cdot 5$ & 100 & V. slight chorea \\
\hline S.M. & M. & $11 \frac{1}{2}$ & $25 \cdot 7$ & 4 & 105 & Severe chorea \\
\hline W.I. & M. & 10 & $24 \cdot 2$ & 4 & 100 & Tapeworm \\
\hline J.M. & F. & $1 \frac{1}{2}$ & $8 \cdot 2$ & 4 & 33 & Chloroma \\
\hline М.M. & F. & 9 & $19 \cdot 6$ & 4 & 80 & Chorea \\
\hline M.F. & $\mathrm{F}$. & 7 & $18 \cdot 83$ & 4 & 76 & , \\
\hline F.F. & M. & 9 & 25 & 4 & 100 & , \\
\hline M.F. & $\mathrm{F}$ & 10 & 23 & 4 & 100 & , \\
\hline J.H. & M. & $10_{2}^{\frac{1}{2}}$ & $27 \cdot 8$ & 4 & 112 & , \\
\hline A.McK. & $\mathrm{F}$ & 12 & $23 \cdot 6$ & 4 & 100 & Tapeworm \\
\hline J.McL. & F. & 10 & $21 \cdot \tilde{3}$ & $4 \cdot 5$ & 100 & Chorea \\
\hline J.M. & $\mathrm{M}$. & 7 & $19 \cdot 4$ & $4 \cdot 5$ & 90 & , , \\
\hline M.T. & F. & 12 & 23 & (; & 138 & , \\
\hline G.G. & F. & 6.12 & 20 & 6 & 120 & , \\
\hline M.B. & F. & $\delta_{2}^{1}$ & $15 \cdot 8$ & 8 & 128 & Neuro.-syphillis \\
\hline R.MeG. & F. & $51 \stackrel{1}{1} \stackrel{2}{2}$ & 15 & 8 & 120 & Chorea \\
\hline R.McM. & $\mathrm{M}$. & 11 & 27 & 10 & 270 & Rheumatism \\
\hline W.K. & M. & $3{ }_{1}^{*}$ & 10 & 11 & 110 & Rickets \\
\hline
\end{tabular}

Group II. Glucose tolerance test in 11 'abnormal' children.

Group II includes 11 cases in which some disturbance of carbohydrate metabolism might be expected and the results are detailed in Tables III and IV respectively according to whether glycosuria was produced or not. The doses of glucose taken by the cases in Group II are unfortunately on the whole much smaller than those taken by the children in Group I. None of the cases in Group II was able to take as much as $100 \mathrm{grm}$. of glucose without nausea and vomiting, and hence it is just possible that had those cases which 
TABLE III.

Cases in which Glycosuria occurred.

\begin{tabular}{|c|c|c|c|c|c|c|c|}
\hline Case & Sex & $\begin{array}{l}\text { Age. } \\
\text { Years }\end{array}$ & $\begin{array}{l}\text { Weight } \\
\text { Kgrm. }\end{array}$ & $\begin{array}{c}\text { Glucose } \\
\text { per kgrm. } \\
\text { of body wt. }\end{array}$ & $\begin{array}{l}\text { Amt. of } \\
\text { glucose. } \\
\text { Grms. }\end{array}$ & Disease & $\begin{array}{l}\text { Sugar } \\
\text { in } \\
\text { urine }\end{array}$ \\
\hline J.McG. & м. & 11 & 28 & 1 & 29 & ? Pituitary tumour & + \\
\hline W.W. & M. & 12 & 53 & $1 \cdot 5$ & $79 \cdot 5$ & Ps-hyp. musc. dyst. & + \\
\hline D.F. & F. & $5_{1}^{\frac{2}{2}}$ & $9 \cdot 67$ & $3 \cdot 7$ & 36 & Dwarf. ? Renal & + \\
\hline A.McG. & M. & 6 & $12 \cdot 63$ & $5 \cdot 5$ & 70 & Dwarf & + \\
\hline J.McM. & M. & 7 & $11 \cdot 4$ & $6 \cdot 5$ & 75 & Dwarf & + \\
\hline M.H. & F. & 372 & $8 \cdot 48$ & 7 & $59 \cdot 5$ & Dwarf & + \\
\hline
\end{tabular}

did not show any sugar in the urine (Table IV) been able to ingest larger amounts of glucose, their sugar tolerance would also have been broken. In 5 of the 11 cases $(54 \%)$ glycosuria resulted with amounts of glucose varying from 1 to 7 grm. per kgrm. of body weight.

TABLE IV.

Cases in which no Glycosuria resulted.

\begin{tabular}{|c|c|c|c|c|c|c|}
\hline Case & Sex & $\begin{array}{l}\text { Age. } \\
\text { Years }\end{array}$ & $\begin{array}{l}\text { Weight } \\
\text { Kgrm. }\end{array}$ & $\begin{array}{l}\text { Glucose per } \\
\text { kgrm. of } \\
\text { body weight }\end{array}$ & $\begin{array}{c}\text { Amt. of } \\
\text { glucose. } \\
\text { Grm. }\end{array}$ & Disease \\
\hline A.McM. & F. & 11 & $38 \cdot 4$ & $2 \cdot 1$ & 80 & ? Pituitary disease \\
\hline C.V. & M. & $2 \frac{1}{4}$ & 10 & 3 & 30 & Pituitary tumour \\
\hline A.S. & F. & 34 & $7 \cdot 4$ & 3 & 23 & $\begin{array}{l}\text { Dwarf. Improved } \\
\text { on pituitrin }\end{array}$ \\
\hline D.H. & M. & $11 \frac{3}{4}$ & $14 \cdot 6$ & $\tilde{5}$ & 73 & Dwarf \\
\hline N.O. & M. & 6 & $11 \cdot 8$ & 6 & 72 & Dwarf \\
\hline
\end{tabular}

\section{Discussion.}

A comparison of Groups I and II does not permit of any definite conclusions but it is clear that the normal child can take a large quantity of glucose without glycosuria supervening. The significance of the low sugar tolerance (l grm. per kgrm.) presented by J.McG. (Table III) who showed signs of pituitary tumour (optic neuritis and enlarged sella turcica) is counterbalanced by that in the case of A.H. (Table I) who seemed, apart from chorea, to be perfectly normal. Hence it is not justifiable to hypothecate any endocrine disturbance in the presence of either an increased or reduced sugar tolerance.

Seven of the cases in Group II were dwarfs, and in 4 of these the tolerance was broken, but since 3 were able to ingest quantities of glucose exceeding $5 \mathrm{grm}$. per kgrm. of body weight it cannot be said that a reduced sugar tolerance is necessarily to be expected in cases presenting any special lack of growth. 


\section{The Blood-sugar Curve and Renal Threshold.}

The effect of a large quantity of glucose on the blood-sugar curve of 10 apparently normal children was studied. The details of the results are given in Table V. Eight of the children were recovering from an attack of chorea, one (Case 6) was convalescent from rheumatic arthritis and another (Case 5) had recently been treated for tapeworm, but during the period of study there was no sign of segments or ova in the fæces. All the children with one exception (Case 5) were receiving 90 grains of sodium salicylate and 180 grains of sodium bicarbonate daily, but this was omitted on the morning of the day of the test. On one occasion, by inadvertence, a child received 15 grains of sodium salicylate and 30 grains of sodium bicarbonate immediately after the glucose had been given. The blood-sugar curve obtained on that occasion did not differ in any marked degree from that obtained when the test was repeated with glucose alone. During the period of study the children were confined to bed and received the routine mixed diet. One gramme of glucose per kgrm. of body weight was given for the first test, and some days later, for the second test, a total of 100 grm., excepting in cases 8 and 10 where 121 and $88 \mathrm{grm}$. were given respectively. MacLean's ${ }^{6}$ method was used to estimate the blood-sugar values. The urine was collected, where possible at half-hourly intervals, and tested for the presence of sugar.

The generally accepted normal fasting blood-sugar value in the adult lies between $\cdot 07 \%$ and $\cdot 120 \%$ with an average value of $\cdot 100 \%$. Bass ${ }^{7}$ found in a series of normal children that the fasting level did not differ from that of adults. In the cases reported here the fasting value of the blood-sugar varied from $\cdot 067 \%$ to $\cdot 166 \%$, the average being $\cdot 106 \%$. Only three children gave fasting values above the accepted adult maximum value of $120 \%$. Each of these latter cases was observed for a period of three months in hospital, but during that time presented no evidence of disturbed carbohydrate metabolism. In one (Case 9 ) the high value of $\cdot 152 \%$ was exceptional, since on eight other occasions on which the fasting value was estimated, it was found to lie between $.082 \%$ and $\cdot 103 \%$. Gray ${ }^{3}$ in his review of the literature found that $7 \%$ of 900 apparently normal individuals had a fasting blood-sugar value within the limits of $\cdot 120 \%$ and $\cdot 160 \%$, so that these high fasting values, though unusual, need not necessarily be considered pathological.

The duration of the starvation did not seem to affect the fasting level, the average value being $\cdot 106 \%$ after an 8 hours' abstinence from food and $\cdot 107 \%$ after after a period of 15 hours. It was also noted that this fasting level was not constant, but varied somewhat on the different days on which it was estimated, as can be seen from the details given in Table $V$. Other observers have noted this same fact. Hale-White and Payne ${ }^{8}$ found that the same individual did not give similar types of curves on different occasions.

With one exception, the peak of the curve, after the smaller amount of glucose ( $1 \mathrm{grm}$. per kgrm. of body weight) occurred within the hour. The average highest value reached was $\cdot 173 \%$, the maximum and minimum being $\cdot 204 \%$ and $\cdot 141 \%$ respectively. Generally speaking the results agree with those obtained by MacLean ${ }^{6}$ and other workers for the normal adult after a 
TABLE V.

Blood-Sugar Curves in Normal Childrex.

\begin{tabular}{|c|c|c|c|c|c|c|c|c|c|c|c|}
\hline \multirow{3}{*}{$\begin{array}{l}\text { Case } \\
\text { No. }\end{array}$} & \multirow{3}{*}{$\begin{array}{l}\text { Weight } \\
\text { Kgrm: }\end{array}$} & \multirow{3}{*}{$\begin{array}{l}\text { Amt. of } \\
\text { glucose } \\
\text { in Grm. }\end{array}$} & \multirow{3}{*}{$\begin{array}{l}\text { Dur. of } \\
\text { fast in } \\
\text { hours. }\end{array}$} & \multicolumn{7}{|c|}{ Percentage of sugar in the blood } & \multirow{3}{*}{$\begin{array}{l}\text { Sugar } \\
\text { in } \\
\text { urine }\end{array}$} \\
\hline & & & & \multirow{2}{*}{$\begin{array}{r}\text { Fast- } \\
\text { ing }\end{array}$} & \multicolumn{6}{|c|}{ Hours after glucose } & \\
\hline & & & & & $\frac{1}{2}$ & 1 & $1 \frac{1}{2}$ & 2 & $2 \frac{1}{2}$ & 3 & \\
\hline 1 & $27 \cdot 2$ & $\begin{array}{r}28 \\
100\end{array}$ & $\begin{array}{l}8 \\
8\end{array}$ & $\begin{array}{l}\cdot 106 \\
\cdot 102\end{array}$ & $\begin{array}{l}.166 \\
.211\end{array}$ & $\begin{array}{l}.204 \\
.227\end{array}$ & $\begin{array}{l}.189 \\
.217\end{array}$ & $\begin{array}{l}\cdot 162 \\
.193\end{array}$ & $\cdot \overline{166}$ & - & $\begin{array}{c}\text { Absent } \\
,,\end{array}$ \\
\hline 2 & $22 \cdot 8$ & $\begin{array}{r}23 \\
100\end{array}$ & $\begin{array}{l}15 \\
15\end{array}$ & $\begin{array}{l}\cdot 141 \\
\cdot 166\end{array}$ & $\begin{array}{l}.152 \\
.191\end{array}$ & $\begin{array}{l}\cdot 196 \\
\cdot 193\end{array}$ & $\begin{array}{l}\cdot 172 \\
.226\end{array}$ & $\begin{array}{l}.129 \\
.234\end{array}$ & $\overline{.191}$ & - & ", \\
\hline 3 & $26 \cdot 36$ & $\begin{array}{r}27 \\
100\end{array}$ & $\begin{array}{l}15 \\
15\end{array}$ & $\begin{array}{l}\cdot 109 \\
.090\end{array}$ & $\begin{array}{l}.115 \\
.162\end{array}$ & $\begin{array}{l}\cdot 137 \\
\cdot 202\end{array}$ & $\begin{array}{l}\cdot 141 \\
\cdot 216\end{array}$ & $\begin{array}{l}\cdot 125 \\
\cdot 181\end{array}$ & $\cdot \overline{198}$ & $\overline{-}$ & " \\
\hline 4 & 28.04 & $\begin{array}{r}28 \\
100\end{array}$ & $\begin{array}{l}15 \\
15\end{array}$ & $\begin{array}{l}\cdot 100 \\
\cdot 100\end{array}$ & $\begin{array}{l}.125 \\
.179\end{array}$ & $\begin{array}{l}\cdot 152 \\
\cdot 179\end{array}$ & $\begin{array}{l}\cdot 109 \\
\cdot 191\end{array}$ & $\begin{array}{l}\cdot 121 \\
\cdot 129\end{array}$ & $\overline{-131}$ & - & " \\
\hline 5 & $22 \cdot 6$ & $\begin{array}{r}24 \\
100\end{array}$ & $\begin{array}{r}8 \\
15\end{array}$ & $\begin{array}{l}\cdot 119 \\
.098\end{array}$ & $\begin{array}{l}.204 \\
.214\end{array}$ & $\begin{array}{l}.196 \\
.243\end{array}$ & $\begin{array}{l}.158 \\
.286\end{array}$ & $\begin{array}{l}.111 \\
.296\end{array}$ & $\overline{\cdot 196}$ & $\frac{-}{-}$ & " \\
\hline 6 & $26 \cdot 7$ & $\begin{array}{r}27 \\
100\end{array}$ & $\begin{array}{l}8 \\
8\end{array}$ & $\begin{array}{l}\cdot 113 \\
\cdot 106\end{array}$ & $\begin{array}{l}\cdot 137 \\
\cdot 184\end{array}$ & $\begin{array}{l}\cdot 147 \\
\cdot 177\end{array}$ & $\begin{array}{l}\cdot 141 \\
\cdot 141\end{array}$ & $\begin{array}{l}\cdot 109 \\
\cdot 108\end{array}$ & - & - & $"$ \\
\hline 7 & 25 & $\begin{array}{r}25 \\
100\end{array}$ & $\begin{array}{r}15 \\
8\end{array}$ & $\begin{array}{l}\cdot 127 \\
\cdot 100\end{array}$ & $\begin{array}{l}.181 \\
.250\end{array}$ & $\begin{array}{l}\cdot 189 \\
\cdot 310\end{array}$ & $\begin{array}{l}.123 \\
.270\end{array}$ & $\begin{array}{l}.141 \\
.207\end{array}$ & $\overline{139}$ & - & " \\
\hline 8 & $20 \cdot 16$ & 121 & 8 & $\cdot 110$ & $\cdot 174$ & $\cdot 193$ & $\cdot 168$ & .094 & - & -\{ & $\begin{array}{l}\text { Absent } \\
\text { Abs. at } \\
\& 1 \mathrm{hr} . \\
+ \text { at } 1 \frac{1}{2} \\
\text { hrs. }\end{array}$ \\
\hline 9 & $21 \cdot 6$ & $\begin{array}{r}22 \\
100 \\
100\end{array}$ & $\begin{array}{l}15 \\
8 \\
8\end{array}$ & $\begin{array}{r}.095 \\
\cdot 152 \\
\cdot 102\end{array}$ & $\begin{array}{r}.179 \\
.256 \\
.211\end{array}$ & $\begin{array}{r}.159 \\
.341 \\
.239\end{array}$ & $\begin{array}{l}.129 \\
.321 \\
.268\end{array}$ & $\begin{array}{r}.113 \\
.264 \\
.251\end{array}$ & $\begin{array}{l}- \\
.241 \\
-\end{array}$ & $\begin{array}{c}- \\
\cdot 196 \\
\cdot 211\end{array}$ & $\begin{array}{l}\text { Absent } \\
\text { Abs.at } \frac{1}{2} \\
+ \text { at 1 } \\
\& 3 \text { hrs. } \\
\text { Absent }\end{array}$ \\
\hline 10 & $17 \cdot 8$ & $\begin{array}{l}88 \\
88\end{array}$ & $\begin{array}{r}8 \\
15\end{array}$ & $\begin{array}{l}.067 \\
.088 \\
.088\end{array}$ & $\begin{array}{l}- \\
.184\end{array}$ & $\begin{array}{r}.113 \\
.182 \\
.216\end{array}$ & $\begin{array}{l}.081 \\
\\
.286 \\
.184\end{array}$ & - & - & $\begin{array}{l}- \\
-\{ \\
-\end{array}$ & $\begin{array}{l}\text { Absent } \\
\text { Abs. at } \\
\& 1 \mathrm{hr} . \\
+ \text { at } 1 \frac{1}{2} \\
\text { hrs. } \\
\text { Absent }\end{array}$ \\
\hline
\end{tabular}

meal of $\mathbf{5 0} \mathrm{grm}$. of glucose, except that the curve does not return so quickly to the fasting level. This may be due to the relatively larger amount of glucose which the children ingested, or to the longer fasting period, or to a combination of both these factors. It is well known that a second dose of glucose, ingested 
during a falling blood-sugar, produces a very slight (if any) secondary rise. This is usually explained on the hypothesis that the carbohydrate storage mechanism of the body is already mobilized and able to deal immediately with the second quantity of glucose. Since many of the workers including MacLean and De Wesselow ${ }^{9}$ have used fasting periods of only 3 to 5 hours, it may be that the carbohydrate storage mechanism was in their cases not yet demobilized and could deal quickly with any glucose ingested, hence the more rapid fall to fasting level recorded by these workers than was found in our series in which the fasting period was either 8 or 15 hours. It has not, however, been universally accepted that the fasting level should be reached within 2 hours. Some observers accept 3 hours as the time interval, and HaleWhite and Payne ${ }^{8}$ suggest that a value of $\cdot 120 \%$ is quite within normal limits at the end of 2 hours.

With the larger amounts of glucose somewhat different results were obtained. The maximum value obtained was very much higher, the average value being $\cdot 25 \%$, and the maximum and minimum $\cdot 341 \%$ and $\cdot 184 \%$ respectively. The maximum value was attained in $50 \%$ of the patients at a time later than was the case after the small dose of glucose. In only one instance (Case 6 ) was a curve produced resembling that described by MacLean ${ }^{6}$ for adults after $50 \mathrm{grm}$. of glucose. MacLean and De Wesselow ${ }^{9}$ maintain that in normal individuals the height of the curve cannot be raised above the maximum $\cdot 18 \%$ by large doses of glucose, though the fall may be delayed. Hale-White and Payne ${ }^{8}$, however, report blood-sugar curves rising above $\cdot 180 \%$ with doses larger than 25 grm., and Foster ${ }^{10}$ quotes 3 cases where the blood-sugar curve rose to $\cdot 214 \%$ in 30 minutes, $\cdot 204 \%$ in 35 minutes, and $.201 \%$ in 45 minutes respectively after 100 grm. of glucose. Gray ${ }^{3}$ in his analysis found in 300 normal cases a large number in which the blood-sugar curve rose to values between $\cdot 20 \%$ and $\cdot 25 \%$ with 100 grm. of glucose.

From the relationship between the blood-sugar level and the glycosuria in this series of normal children, the renal threshold would seem to be very high in comparison with that obtaining in the adult. The average value of the renal threshold in all the cases lies above $\cdot 238 \%$. In Cases 8,9 and 10 the value can be fairly definitely fixed. In Case 8 it is above $\cdot 246 \%$; in Case 9 it lies between $\cdot 268 \%$ and $\cdot 341 \%$; and in Case 10 between $\cdot 216 \%$ and $\cdot 286 \%$. The test, with the larger dose, was repeated 4 and 6 days later in Cases 9 and 10 respectively. The resulting blood-sugar values were not so high as those obtained with the previous test, and no sugar appeared in the urine. Besides enabling a more definite value to be placed on the renal threshold in these two cases, these results point to the variability of the tolerance for glucose in the same child on different occasions. The values $\cdot 296 \%$ and $\cdot 310 \%$ in Cases 5 and 7 respectively are exceptionally high.

It might be said that the blood-sugar did not remain at these high levels sufficiently long for sugar to appear in the urine in amounts possible of detection by ordinary clinical tests. But in Cases 2 and 3 the level of the blood-sugar was above $\cdot 200 \%$ for at least one $\frac{1}{2}$-hour, in Case 1 for one hour, in Cases 5 and 7 for 2 hours and in Case 9 for 3 hours. It can be seen, therefore, 
that this criticism is not valid, the time during which the blood-sugar was at a high level being sufficiently long for sugar to have been excreted in easily recognizable amounts.

Glucose has been regarded by the majority of workers as a threshold substance, though Benedict and Osterberg ${ }^{5}$ maintain that there is no absolute threshold for glucose and no sudden point at which sugar appears in the urine. MacLean and De Wesselow ${ }^{9}$ consider the level of the renal threshold as $\cdot 180 \%$; Olmstead and Gay ${ }^{11}$ and Graham ${ }^{12}$ place it at $\cdot 190 \%$. Hale-White and Payne ${ }^{8}$ suggest that $\cdot 20 \%$ would be a more reasonable value to consider as the maximum normal renal threshold. MacKay ${ }^{13}$, who examined the blood-sugar of 44 patients during anæsthesia, found that of 30 subjects who developed glycosuria, $37 \%$ had maximal blood-sugar values of less than $\cdot 180 \%$. In 14 of the cases in whom glycosuria was not produced, $86 \%$ had maximal values varying between $\cdot 180 \%$ and $\cdot 386 \%$. In the estimation with the maximal rise of $\cdot 386 \%$, the blood-sugar remained above $\cdot 200 \%$ for 4 hours without any sugar appearing in the urine. MacKay ${ }^{13}$ suggests that the renal threshold may vary considerably in different individuals, and Greenwald, Gross and Samet ${ }^{14}$, who also subscribe to this view, think that the threshold may vary in the same individual at different times. Graham ${ }^{12}$ mentions one case, but without any particulars, where a blood-sugar value of over $\cdot 300 \%$ was obtained without glycosuria. Host ${ }^{15}$ found that of 14 normal women two gave a maximal value of $\cdot 200 \%$ without glycosuria resulting.

The examples from the literature quoted above show that a higher renal threshold than $\cdot 180 \%$ does exist in the normal adult and that it may be even above $\cdot 20 \%$, but no cases have been described where, after ingesting glucose, such typically diabetic curves have been obtained as are described in the present series of cases, where $80 \%$ showed a high renal threshold and diabetic type of curve. It must be remembered, however, that blood-sugar curves, following amounts of glucose relatively as large as those given to the children in this present series (i.e., roughly $4 \mathrm{grm}$. of glucose per $\mathrm{kgrm}$. of body weight), have rarely been estimated in the adult. It is therefore possible that if the adult could.take such relatively large amounts ( $240 \mathrm{grm}$.) without nausea and sickness, the blood-sugar could be raised in a proportion of cases to an unduly high level without the production of glycosuria. The renal threshold in the majority of diabetics lies well above $\cdot 20 \%$, and it has generally been assumed that this has been raised above the normal. In the normal child there is obtained after large amounts of glucose a blood-sugar curve which resembles that met with in diabetics after a small quantity of glucose. It might be suggested, therefore, that in a certain number of cases of diabetes mellitus the level of the renal threshold for sugar has not been raised but is at its normal level.

\section{Summary AND Conclusions.}

1. In children, apparently normal as far as carbohydrate metabolism is concerned, so-called 'sugar tolerance' is very variable. In most cases glycosuria cannot be produced by any amount of glucose that can be ingested 
and absorbed, but the sugar tolerance has been broken by a quantity as low as $1 \mathrm{grm}$. per $\mathrm{kgrm}$. of body weight. As much as $11 \mathrm{grm}$. of glucose per kgrm of body weight can be taken without glycosuria supervening.

2. In disturbances of the endocrine system, and in cases showing any special lack of growth, no clear cut conclusions as to the finding of either a decreased or an increased sugar tolerance can be drawn.

3. In children, with amounts of glucose equal to $1 \mathrm{grm}$. per kgrm. of body weight, the blood-sugar curve is similar to that found in adults. With larger quantities of glucose the curve is, in the majority of cases, at a much higher level, and the fall is delayed beyond 2 hours.

4. The renal threshold for sugar would seem to be variable but to lie somewhere in the region of $\cdot 23 \%$ in the majority of children.

\section{REFERENCES.}

1. Wright, S., Applied Physiology, Oxford, 1928, 416.

2. Taylor, A. E., \& Hulton, F., J. Biol. Chem., Baltimore, 1916, XXV, 175.

3. Gray, H., Arch. Int. Med., Chicago, 1923, XXXI, 241.

4. Goto, K. \& Kuno, N., Ibid., 1921, XXVII, 224.

5. Benedict, S. R., Osterberg, E., \& Neuwirth, I. J. Biol. Chem., Baltimore,, 1918 XXXIV 217, \& LV, 769.

6. MacLean, H., Modern Methods in the Diagnosis and Treatment of Diabetes and Glycosuria, Lond., 1927.

7. Bass, M. H., Amer. J. Dis. Child., Chicago, 1915, XI, 63.

8. Hale-White, R., \& Payne, W. W., Quart. J. Med., Oxford, 1925-26, XIX, 393.

9. MacLean, H., \& De Wesselow, O. L. V., Ibid., 1920-21, XIV, 103.

10. Foster, G. L., J. Biol. Chem., Baltimore, 1923, LV, 291.

11. Olmstead, W. H., \& Gray, L. P., Arch. Int. Med., Chicago, 1922, XXIX, 384.

12. Graham, G., Quart. J. Med., Oxford, 1922-23, XVI, 236.

13. Mackay, R. L., Biochem. J., Cambridge, 1927, XXI, 760.

14. Greenwald, I., Gross, J., \& Samet, J., J. Biol. Chem., Baltimore, 1924, LXII, 401.

15. Host, H. F., Lancet, Lond., 1925, i, 1022. 